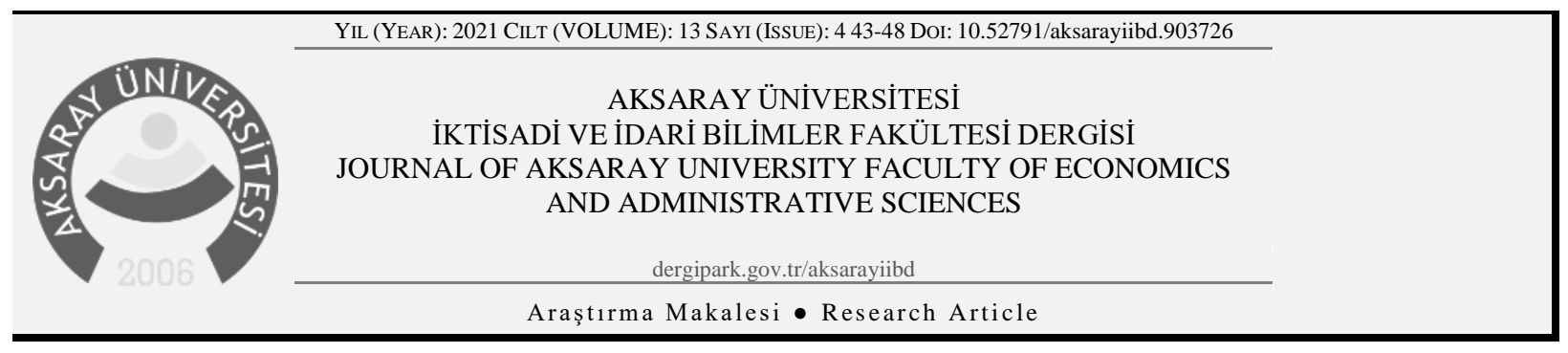

\title{
Rethinking the Transition to Democracy in the Cases of Military Rule, Religion and Economic Development
}

\author{
Askeri Yönetim, Din ve Ekonomik Kalkınma Bă̆lamında Demokrasiye Geçişi Yeniden \\ Düşünmek
}

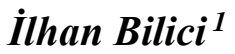 \\ ${ }^{I}$ Arş. Gör., Recep Tayyip Erdoğan Üniversitesi, İktisadi ve İdari Bilimler Fakültesi, Siyaset Bilimi ve Kamu Yönetimi Bölümü, \\ bilici.ilhan61@gmail.com, Orcid Id:0000-002-4085-7274
}

\begin{tabular}{l} 
A R T I C L E I N F O \\
\hline Keywords \\
Democratization, \\
Democracy, \\
Military Rule, \\
Economic Development, \\
Religion \\
\hline Article History: \\
Received: 26 March 2021 \\
Accepted: 2 October 2021 \\
M A K A L E B İ L G İ I İ \\
\hline Anahtar Kelimeler \\
Demokratikleşme, \\
Demokrasi,, \\
Askeri Yönetim, \\
Ekonomik Kalkinma, \\
Din
\end{tabular}

Makale Geçmiși:

Geliş Tarihi: 26 Mart 2021

Kabul Tarihi: 2 Ekim 2021

\begin{abstract}
A B S T R A C T
Studies of democratization have developed and have become increasingly more sophisticated across the past 20 years as a result of new datasets being completed and shared. Scholars have written widely on the subject and have offered explanations of transitions to democracy, but some of these explanations are incoherent with others. This paper offers a discussion of a variety of conditions which provide fertile soil for transitions to democracy, ranging from military rule and religion to economic development. Addressing this contestation, the paper argues that there is no single explanation for the transition to democracy and that it requires very sophisticated thinking to determine the conditions for democratization.
\end{abstract}

\section{Ö Z E T}

Yeni veri setlerinin tamamlanması ve paylaşılmasıyla birlikte özellikle son 20 yılda demokratikleşme çalışmaları gelişti ve giderek daha da karmaşık bir hal almaya başladı. Siyaset bilimciler konuyla ilgili geniş çapta yazılar kaleme almakta ve demokratikleşme sürecine ilişkin çeşitli teorik temellendirmeler geliştirilmektedir, ancak bu temellendirmelerin bazıları birbiriyle çelişir niteliktedir. Bu çalışma, askeri yönetim, din faktörü ve ekonomik kalkınma bağlamında demokratikleşmeye zemin hazırlayan veya demokratikleşmeyle ilişkilendirilen bu koşulların teorik bazda tartışmasını sunmaktadır. Çalışmada ayrıca, demokrasiye geçiş için tek bir açıklamanın yeterli olmadığı ve demokratikleşme için asgari olan şartların neler olduğunu belirlemek için çok karmaşık bir düşüncenin gerekli olduğu ileri sürülmektedir.

$\mathrm{D}$

uring the third wave of democratization, the idea of democracy was no longer seen as a Western phenomenon, but had become a global one (Diamond, 2010). At the beginning of the third wave in mid-1974, there were only approximately forty democratic states in southern Europe, and just a couple of them were situated outside the West, such as South Korea and Thailand (Lipset, 1994; Bunce, 2000). The number of democratic states increased from 76 to 117 between 1990 and 1995 (Diamond, 2010). Even though a democratic presence has become accepted in various cultures, the Arab world seems to be an exception since democracy is weakest in this setting (Diamond, 2010). Lipset (1994) claimes that a legitimate democratic system might be difficult to establish within countries with former authoritarian regimes, since their histories, beliefs and traditions might be contrary to the mechanisms of democracy.

Studies of democratization have developed and have become increasingly more sophisticated across the past 20 years. Studies of democratization have also altered significantly as a result of new datasets being completed and shared (Geddes, 
2007; Bunce, 2000). Scholars have written widely on the subject and have offered explanations of transitions to democracy, but some of these explanations are incoherent with others (Geddes, 1999). On the one hand, modernization theorists have proclaimed the importance of socio-economic development - consisting of industrialization and high levels of education and urbanization. Others, however, have acknowledged "culture and religion, diversity, oil and natural resources" as dynamics which could expand or deter the prospects of a country seeking for democratic change (Hadenius and Teorell, 2007, p. 113). Moreover, there is a significant controversy among scholars over economic development and whether it enhances the probability of transition to democracy: some have argued that there is a relationship between development and transition to democracy, others have claimed that economic development decreases the probability of democratic collapse rather than bringing about democratization (Geddes, 2007). It is fair to say that the main problem which analysts face might be that the process of democratization differs greatly from place to place and from case to case. Generalizing these cases or places fails to articulate all the real-world variations (Geddes, 1999). This paper addresses this contestation, arguing that there is no single explanation for the transition to democracy and that it requires more discussions and research findings to determine the conditions for democratization.

The paper first offers an analysis of the role of military rule in the transition to democracy. A discussion follows on how religion, and in particular Islam, determines the process of democratization, if it does at all. The discussion then traces the relationship between economic development and democratization. Among the explanations of transition to democracy, this paper specifically focuses on military rule, religion and economic development because these three approaches are the most controvertial ones utilised in understanding transitions to democracy.

\section{THE ROLE OF MILITARY RULE IN DEMOCRATIZATION}

It is a known fact that the biggest threat to democracy today and in the past is the military (Bunce, 2003). Although the long history of military coups demonstrates that most military interventions ended democracy, as in Latin American countries, some brought about a transition to democracy (Bunce, 2003). Some of the military officers who had guided the liberation activities turned out to be authoritarian rulers, as in the post-colonial Arab world (el-Husseini, 2016). A self-declared "guardianship" over the nation was established by military governments through control of economic and political institutions (Said, 2012, p. 398). It is therefore necessary to ask how these non-democratic governments might revert to be democratic.

Geddes (2007) argues that governments controlled by the military are more fragile and breakable than other varieties of authoritarian regimes because poor economic performance easily destabilizes them. It is a truism that the survival of all forms of governments, which are either democractic or non-democratic, are thetatend by economic crises (Geddes, 1999). Additionally, the military is trained for military purposes, but not for governance (Frank and Ukpere, 2012). That is why poor economic performance, which could stem from statist economy, makes military goverments more vulnerable to economic downturns than any other non-democratic regimes. This circumtance at long last leads to parts within the officer corps. Besides, it is argued that there might be factions and splits among officers regarding how to respond to crises, and it is stated that these factions result in many officers' wish to get back to their barracks so as to reunite the armed forces (Geddes, 2007). According to the literature on Latin American transitions, the fear of factionalism within the military elite is seen as a first step towards liberalization (Geddes, 1999). Because of this fear, military officers tend to negotiate the process of the transition to democracy in an orderly way (Geddes, 1999, 2007). However, Bunce (2003) claimes that the effect of mass mobilizations forced the authoritarian rule to step down and that this effect promoted the democratic project in the postcommunist region. That is to say, the people mobilize on behalf of democracy. This was the case in South Korea that there was a large-scale demonstration against military rule resulted in negotiations with opposition parties about a new constitution and direct presidential elections in mid-1987 (Barany, 2015). There are other cases where the military rulers have abandoned participation in politics: one such case is that once they become ineffective and unpopular rulers, an effective and popular opposition eventually replaces them, as in Argentina in 1983; another is that they keep their promises about calling for free and fair elections and respect the results, as in Turkey in 1983 (Barany, 2015).

\section{THE ROLE OF RELIGION FOR TRANSITION TO DEMOCRACY}

As it was mentioned previously, the present paper limits its scope only to military rule, religion and economic development because of their polemical roles in exploring transitions to democracy. In this connections, this part of paper pays particular attention to the relationship between religion, particularly Islam, and democracy and seeks to answer why Muslim or Arab countries fall behind on democracy.

Religion has been arguably a main factor for transition to democracy. The relationships between democracy and Catholicism, Orthodox Christianity, Islam, and Confucianism have been negatively interlinked, whereas there has been a positive relationship between Protestantism and democracy (Lipset, 1994). Lipset (1994) explains these differences by suggesting that 
individualism plays a crucial role in Protestantism and that there is a close relationship between the state and religion in the other faiths. It has been argued that the separation of religious and political institutions advances democracy (Tocqueville, 1998). However, the separation of God and Caesar does not strongly take place even today in many established European democracies in which state churches have been founded. Additionally, it is noted by Fish (2002, p. 21) that "church and state in Germany are intertwined in education, taxation, social service provision and finance." Similarly, although Orthodox Christian countries have appeared to resist democratization, some states such as Serbia and Yugoslavia have achieved significant reform, and there are democratically-elected governments in Russia and the Ukraine, where this type of election has become the norm (Karatnycky, 2002). That is to say, the separation may not be a necessary condition for democratization and all Western countries somehow have already transited to democracy whether they are affiliated with the church or not. Whilst these states became democratic entities, Muslim countries, and in particular Arab states, have remained authoritarian (Lipset, 1994). It is also most unlikely to expect Arab states to make the separation of religion and politics in a single year, namely all at once (Grugel and Bishop, 2014). It is therefore necessary to ask whether Islam is an obstacle to democratization, or not.

To the contrary of common belif, Islam can prepare a good social-economic base for democratization with a well-functioning free market economy and non-radical islamic interpretation. In order to understand the degree to which countries adopt and implement the democratic system, it is necessary to focus more on social-economic and historical reasons than religious factors. In reality, islamic countries, like other developing countries, face socio-economic chalenges that thwart the establishment of democracy. Poverty, income inequality, feudal ties, low education level, and authoritarian leaderns masquerading as democratic leaders are the obstacles to democratization, and they play a critical role in democratization. There are, therefore, many institutional, structural, and cultural explanations which articulate why Muslim world has been slow to the process of democratization (el-Husseini, 2016). One explanation regards Islam as a barrier to democratization and the influence of religion in the political environment is attributed to authoritarianism (Lipset, 1994). Others claim that it has relatively little to do with religion itself but more to do with other dimensions such as dependency on oil exports, ethnic diversity, a history of British colonization and, importantly, the status of women (Fish, 2002; Ross, 2008). However, what hinders democratization most in Muslim states is the treatment of women (Fish, 2002). Fish (2002) suggests that literacy rates and sex-ratio imbalances differentiate between male and female in a way that reflects the social relations in the family structure and the society, and that the traits of these relationships might replicate themselves at the upper stage in a broader society. It has been claimed that the subordination of women might be because of an interpretation of Islam which downgrades women to a second-class position and thus imposes a cultural burden on the democracy gap in the region (Karatnycky, 2002). Some scholars have found that where there is a radical Islamic culture, there are worsened rights of women, such as in Tunisia and Algeria (Chaturvedi and Montoya, 2013).

It has also been argued that the extraction of oil and gas inclines to lessen the position of women in the workplace and the probability that they will gain political influence (Ross 2008). Ross bases her argument on three claims; that women enter the labour force in low- and middle-income states by finding employment with low incomes and in export-oriented factories; that having jobs such as these can strengthen women in terms of political and social status; and that once a state owns a significant amount of oil wealth, it renders industries such as these unproductive, which demoralizes women from taking jobs outside the home (Ross 2009). This notion can easily be found in the most oil-dependent states such as Kuwait, Qatar, and Saudi Arabia, whereas having no or little petroleum has improved the condition for women more quickly, such as in Turkey, Morocco, Tunisia and Lebanon (Ross 2009). Some might ask why women matter that much. Researchers have suggested that the attitudes which men hold are more conducive to authoritarianism whereas women are uncomfortable with inequality and hierarchy, and that men are inferior to women in various features of achieving consensus (Fish, 2002).

Since the majority of the world's Muslim countries have constitutional governments and democratic rule, such as Turkey, Indonesia and Bangladesh, it is wrong to say that Islam is inherently incompatible with democracy (Karatnycky, 2002). Diamond (2010) contends that there is no 'Muslim gap' in terms of democratic deficit, but that there is an Arab gap on the grounds that Freedom House rated eight non-Arab, Muslim-majority countries which hold free and fair elections as democracies, and that none of these are Arab states. Indeed, there are no true democracies or free countries among Arab states (Karatnycky, 2002).

\section{DEVELOPMENT AND DEMOCRACY}

One of the most sophisticated topics of comparative politics is perhaps the relationship between economic growth and democracy. Many scholars have attempted to articulate the role which economic development plays in the process of democratization. Lipset (1959) argues that the democratic political link is formed by economic development, involving industrialization, urbanization, wealth and higher education, and that these four factors are closely interrelated. In other words, these elements form the conditions necessary for democracy. According to this logic, modernization demonstrates 
itself by altering social conditions, which expands the scope of democratic culture. A rise in urbanization, education, the number of people working in factories, and equality, and a decline in traditional loyalties to tribe would bring about tolerance and an attitude of claiming a say, in particular by the middle class, in government (Lipset, 1959). However, Przeworski and Limongi (1997, p. 177) suggests that economic development does not cause the emergence of democracy and whether political actors are seeking their own goals establish democracy or not, "it can be initiated at any level of development". They argue that once democracy is established, economic constraints have an impact: when the country is wealthier, the necessary changes are very much greater for democracy to survive (Przeworski and Limongi, 1997). It has also been stated that even though poor democracies occasionally fall and revert back to dictatorship, this is almost impossible to apply to rich democratic countries. Another counter-argument is that there are many grounds for democratization apart from modernization, such as wars (the Argentine defeat in the Malvinas), the death of a founding dictator (Franco), economic crises and foreign pressures (Przeworski and Limongi, 1997). They also contend that if the modernization theory is true, transitions to democracy would be highly likely once non-democratic governments reach advanced stages of development, however, authoritarian regimes become more stable as states become richer (Przeworski and Limongi, 1997).

Conversely, Boix (2011) finds that per capita income is linked to the process of democratization and that development plays a causal role in democracy in two ways: first the existence of specific institutional structures and the spread of a skilled labour force, and second, declining inequality triggered by economic development, and that the relationship between income and democracy differs according to the levels of income over period of time. On the one hand, income plays a declining marginal role in democratization: in richer countries, any further growth stabilizes them but does not expand the probability of a transition to democracy. On the other hand, the structure of the international order strongly mediates the effect of income and the ways in which the resources of political factions in small states are shaped by great powers (Boix, 2011).

Another counter explanation for the link between democratization and modernization theory (Acemoglu and Robbinson, 2006) is a conflict between the elite and the citizens over social choices and policies. Acemoglu and Robbinson (2006) argued that this was the case in 19th century Europe, particularly in Britain, in which the middle and the working classes demanded right to vote that led to a transition to democracy. When citizens seek democracy, the elite wants to oppose to this and whether the society becomes democratic is determined by the balance of political power between these two groups (Acemoglu and Robbinson, 2006). According to this explanation, the rich, holding central power in authoritarian regimes, always encounters the danger of revolution, while the poor, representing the vast majority of the population cannot achieve any redistribution of wealth. So the rich has three ways, immediate redistribution, democracy or repression, to handle the threat of revolution. It has been argued that redistribution will not be accepted by the poor because redistribution does not warrant any future structure as long as the rich still holds political power, and that democracy occurs "when concessions are not credible and repression is not attractive because it is too costly" to both the rich and the poor (Acemoglu and Robbinson, 2006, p. 30). In sum, income inequality creates the grounds for democratization.

\section{CONCLUSION}

The paper offers a discussion of a variety of conditions which provides fertile soil for transitions to democracy, ranging from military rule and religion to economic development. Military rule is more fragile than other sorts of authoritarian rule in terms of transitions to democracy. Because poor economic performance might easily destabilize military rule, this might cause splits among officers, which might lead to democratization. As for religion, apart from Muslim countries, all other countries, in particular Western states, have made the transition to democracy. An answer has been offered to the question of why Muslim states remain authoritarian. Although some believe that religion is a barrier to transition, others believe that the subordination of women and heavy reliance on natural resources are the barriers to democracy. The paper ended with a discussion of the relationship between economic development and the transition to democracy. The debate over the impact of economic development on political institutions has increasingly dominated the research agenda since the 1950s. Some have argued that there is a correlational relationship between economic development and that subsequently recently democratized countries such as Chile, Spain, South Korea, and Taiwan exemplify the implications of the relationship. Others, however, have contended that there is no relationship between economic development and democratization and that democracy can be achieved by other factors such as wars, economic crises and foreign pressure. A contrasting view is that economic development plays a role in the transition to democracy although this role is relatively small in terms of its effect on the role of development in sustaining democracy. Although the relationship between economic development and democratization is small and weak, the transition to democracy is determined by historical factors rather than economic growth.

\section{REFERENCES (KAYNAKÇA)}

Acemoglu, D., \& Robinson, J.A. (2006). Economic origins of dictatorship and democracy. Cambridge: Cambridge University Press.

Barany, Z. D. (2015). Exits from military rule: Lessons for Burma. Journal of Democracy, 26(2), 86-100. 
Boix, C. (2011). Democracy, development, and the international system. American Political Science Review, 105(4), 809-828.

Bunce, V. (2000). Comparative democratization - big and bounded generalizations. Comparative Political Studies, 33(6-7), 703-734.

Bunce, V. (2003). Rethinking recent democratization: Lessons from the postcommunist experience. World Politics, 55(2), 167-192.

Chaturvedi, N. S., \& Montoya, O. (2013). Democracy, oil or religion? Expanding women's rights in the muslim world. Politics and Religion, 6(3), 596-617.

Diamond, L. (2010). Why are there no Arab democracies?. Journal of Democracy, 21(1), 93-104.

el-Huesseini, R. (2016). Is gender the barrier to democracy? Women, Islam and the 'Arab spring'. Contemporary Islam, 10(1), 53-66.

Fish, M. S. (2002). Islam and authoritarianism. World Politics, 55(1), 4-37.

Frank, E., \& Ukpere, W. (2012). The impact of military rule on democracy in Nigeria. Journal of Social Sciences, 33(3), $285-292$.

Geddes, B. (1999). What do we know about democratization after twenty years?. Annual Review of Political Science. 2, 115-144.

Geddes, B. (2007). What causes democratization?. In C. Boix \& Stokes, S. C. Stokes (Eds.), The Oxford handbook of comparative politics (pp. $317-$ 339). Oxford: Oxford University Press.

Grugel, J., \& Bishop, M. L. (2014) Democratization: a critical introduction. New York, N.Y.: Palgrave Macmillan.

Hadenius, A., \& Teorel, J. (2007). Pathways from authoritarianism. Journal of Democracy, 18(1), 143-157.

Karatnycky, A. (2002). Muslim countries and the democracy gap. Journal of Democracy, 13(1), 99-112.

Lipset, S. M. (1959). Some social requisites of democracy: Economic development and political legitimacy. The American Political Science Review, 53(1), 69-105.

Lipset, S. M. (1994). The social requisites of democracy revisited: 1993 presidential address. American Sociological Review, 59(1), 1-22.

Przeworski, A., \& Limongi, N. (1997). Modernization: Theories and facts. World Politics, 49(2), 155-183.

Ross, M. L. (2008). Oil, Islam and women. American Political Science Review, 102(1), 107-123.

Ross, M. L. (2009). Does oil wealth hurt women? A reply to Caraway, Charrad, Kang and Norris. Politics \& Gender, 5(4), 575-582.

Said, A. (2012). The paradox of transition to 'democracy' under military rule. Social Research, 79(2), 397-434.

Tocqueville, A. D. (1998). Democratization in America. Ware, Hertfordshire: Wordworth Editions. 
